\title{
Suppressed Voices: The Suffering and Silencing of Irish Institutional Abuse Survivors in Áine Phillips's Redress Performances
}

\author{
Kate Antosik-Parsons
}

\section{(2) OpenEdition \\ Journals}

\section{Édition électronique}

URL : http://journals.openedition.org/etudesirlandaises/3798

DOI : $10.4000 /$ etudesirlandaises.3798

ISSN : 2259-8863

\section{Éditeur}

Presses universitaires de Rennes

\section{Édition imprimée}

Date de publication : 30 juin 2014

Pagination : 137-152

ISBN : 978-2-7535-3449-0

ISSN : 0183-973X

Référence électronique

Kate Antosik-Parsons, « Suppressed Voices: The Suffering and Silencing of Irish Institutional Abuse Survivors in Áine Phillips's Redress Performances », Études irlandaises [En ligne], 39-1 | 2014, mis en ligne le 30 juin 2016, consulté le 20 avril 2019. URL : http://journals.openedition.org/ etudesirlandaises/3798; DOI : 10.4000/etudesirlandaises.3798 


\title{
Suppressed Voices: The Suffering and Silencing of Irish Institutional Abuse Survivors in Áine Phillips's Redress Performances
}

\author{
Kate Antosik-PARsons \\ University College Dublin
}

\begin{abstract}
This essay examines Redress (2010-2012), a recent series of performances by Irish artist Áine Phillips that interrogate the legacy of abuse perpetrated in Irish residential institutions in the $20^{\text {th }}$ century and the official efforts to compensate abuse survivors. These powerful performances are imbued with simple, yet compelling bodily gestures informed by spectatorship, memory and representation. Redress embodies the marginalised memories of abuse survivors, revealing the deliberate gaps and silences in Irish hegemonic narratives.

Keywords: History and memory; women - body; women - artistic representations; society and religion

\section{Résumé}

Cette étude concerne Redress (2010-2012), une récente série de performances de l'artiste irlandaise Aine Phillips. Ces performances analysent l'histoire des sévices et des maltraitances perpétrées dans les instituts et foyers publics dirigés par des religieux au XXe siècle ainsi que les démarches officielles entreprises envers les victimes qui ont survécu à ces abus. Très intenses, ces performances sont caractérisées par un langage corporel simple mais fascinant qui fusionne public, mémoire et représentation. Redress défend la mémoire de ces victimes, en montrant les lacunes et les silences de leur histoire au sein d'un dicours hégémonique irlandais.

Mots clés: Histoire et mémoire; femmes - corps; femmes - représentations artistiques; société et religion
\end{abstract}

The performance art of Irish women artists politicised by feminism renders visible the pervasive nature of hegemonic ideologies by interrogating the historical circumstances and contemporary issues dictating the realities of Irish women's lives. Irish performance art imbues the body as a site of negotiation for gendered representations to undermine conservative political, religious and cultural ideologies that seek to maintain control over women's sexual and bodily autonomy. A number of recent live and recorded performances extend these critiques to address the legacy of the physical, sexual and psychological abuse of those within Catholic-run residential institutions throughout Ireland. Works like Amanda 
Coogan's Medea (2001) and Yellow (2009), and Helena Walsh's Invisible Stains (2008) have dealt specifically with the impact of these violations and the repeated marginalisation of survivor experiences ${ }^{1}$. Performance art is an ephemeral, process-based medium that enables Irish artists to respond to the gaps, omissions and deliberate silences in hegemonic narratives thereby allowing for marginalised memories to arise.

This essay focuses on the recent performance series, Redress (2010-2012), by Irish performance artist Áine Phillips (b. 1965, Dublin). Developed over a period of two years, Redress was composed of live and recorded performances that question the cultural stigma of abuse, its traumatic memories and the continuing silencing of survivors ${ }^{2}$. Phillips was educated at the National College of Art and Design (BFA, 1984-88), Limerick School of Art and Design (MA, 1999-2001) and completed a practiced-based PhD at the National College of Art and Design, Dublin (2006-2009) on the subject of autobiography. Her work has been exhibited nationally and internationally, including at the Live Art Development Agency (London) and the prestigious National Review of Live Art (UK). Her feminist artistic practice is characterised by performative embodiments that attempt to unravel ideas about representation and spectatorship in Irish culture. This essay argues that through a series of haunting bodily gestures, the Redress performances negotiate the injustices of abuse and the suppression and silencing of the most vulnerable in Irish society to critique how dominant Irish narratives remember and forget.

As the prevailing moral authority in twentieth-century Ireland, the Catholic Church wielded power over many aspects of political and cultural life while fostering a climate of sexual repression. The Irish Constitution (1937) even went so far as to state: "The State recognises the special position of the Holy Catholic Apostolic and Roman Church as the guardian of the Faith professed by the great majority of the citizens ${ }^{3}$." The collective organisation was largely responsible for providing services for the vulnerable including education and maintaining orphanages and homes for single mothers. In the 1980s, there were increasing calls for secularization of Irish society facilitated by the demand for greater bodily autonomy with regard to contraception, abortion, divorce and homosexuality. Irish feminist

1. Dominic Thorpe's Redress State - Questions Imagined (2010) and Due Process 2 (2011) (in collaboration with Sandra Johnston) can be included in this group. For a detailed analysis of Yellow see Kate Antosik-Parsons, "Bodily Remembrances: The Performance of Memory in Recent Works by Amanda Coogan", Artefact: The Journal of the Irish Association of Art Historians, 3, 2009, p. 6-20.

2. This series includes three live performances and two video works created between 2010-2012. This article focuses specifically on the first and third works that address abuse within residential institutions. The second live performance entitled Redress State (2011) was a two-hour durational work commented on capitalism, economic recession and the banking crisis.

3. Bunreacht na hÉireann (1937) Article 44:1.2 revoked by Fifth Amendment (1972). 
activists, artists and writers working during this time focused their efforts on excavating the historical and contemporary positions of women and others marginalised in society to challenge the oppressive conservatism of the reigning political, social and religious ideologies ${ }^{4}$.

The scandals involving Bishop Eamonn Casey and Father Michael Cleary, both of whom fathered children despite vocally preaching chaste morals and values, contributed to the growing disquiet amongst Irish Catholics 5 . The sheer number of reports of clerical sexual abuse and calculated cover-ups by Church authorities eroded its unquestioned position. Mary Raftery's probing documentary States of Fear (1999) revealed the shocking widespread abuse committed by Catholic religious orders in Ireland and led to public awareness of the endemic abuse of children in the care of the State. The resulting Commission to Inquire into Child Abuse (The Ryan Commission) (1999) enacted the Residential Institutions Redress Act (2002) establishing a grievance board to redress the systematic and sustained physical, sexual and emotional abuse committed against children in care of the State by various religious-run residential institutions such as industrial or reformatory schools, yet it did not prosecute or sanction the individuals involved. The comprehensive Ryan Report (2009) identified a total of one hundred and twenty-nine offending residential institutions including orphanages, homes for the visually and hearing impaired, industrial schools and children's orthopedic hospitals. It asserted that the various levels of abuse led to a permeating climate of fear where children lived in terror ${ }^{6}$. The compensation offered under the Redress Act is based on a number of factors including the severity of the abuse, the extent of physical and mental injuries, psycho-social affects of the treatment and the loss of opportunity resulting from the abuse. Under Section 13.6 any claimant in receipt of reparation is prohibited from disclosing details of the abuse inflicted under a penalty of up to but not exceeding $€ 25,000$, a term of imprisonment not exceeding two years, or both ${ }^{7}$. The Redress performances directly address the Redress Act and its "gagging" of compensated abuse survivors while also responding to the exclusion from these restitution proceedings of women incarcerated in the religious-run Magdalene Laundries, work homes for women who endured appalling violations of human rights. The Channel 4 docu-

\footnotetext{
4. Noted examples can be found in the writing of Ailbhe Smyth, Eavan Boland, Eiléan Ní Chuilleanáin, Nuala Ní Dhomnaill, Medbh McGuckian and in the artwork of Pauline Cummins, Alanna O'Kelly and Mary Duffy. See Eavan Boland, A Kind of Scar: The Woman Poet in National Tradition, Dublin, Attic Press, 1989.

5. See Diarmaid Ferriter, Occasions of Sin: Sex and Society in Modern Ireland, London, Profile Books, 2009, 528531.

6. The Ryan Report (2009) Executive Summary [http://www.childabusecommission.com/rpt/ExecSummary.php] Accessed June 27, 2012.

7. Section 34, Residential Institutions Redress Act, 2002, [http://www.irishstatutebook.ie/pdf/2002/en.act.2002.0013. pdf Accessed May 31, 2012.
} 
mentary Sex in a Cold Climate (1997) shed light on the subject. Until recently, the glaring omission of these forgotten women was due to lack of official government recognition on the nature of the offenses committed against individuals in these facilities ${ }^{8}$. The invisibility and different types of silencing of these victims and the pervading climate of oppression in these institutions inform these powerful performances.

Redress (2010) (Fig. 1) was a four-hour durational performance initially developed for Right Here, Right Now, a live performance event co-curated by Dominic Thorpe, Niamh Murphy and Amanda Coogan'. For the performance Phillips was locked in a stark cell as she struggled to repeatedly dress herself in an ill-fitting white dress. Her body covered entirely in white make-up, she looked like an apparition. Her white underwear was exposed when she raised her arms suspending the dress overhead. The white wool blanket with a pink border on the wooden floor was reminiscent of a blanket found in a hospital or institution. A bright light angled from the door of the cell lit her body projecting its clearly defined shadow against the rear wall. This visible split between the physical body and its darkened Other suggested the purpose of this performance was to traverse the division between the visible, tangible and the shadowy repression of silence. Her pale, spectral presence underscored the possibility of the re-emergence of the past. The location of this performance in Kilmainham Gaol drew parallels with Dorothy Cross's Caught in a State (1991), Rita Duffy's Belfast Pieta (1991) and Louise Walsh's In-laws/Outlaws (1991), previous installations in this location that used Irish history and memory to address pressing issues of gender and sexuality in Irish society. Nineteen years later, the performance of Redress in this same space resonated with haunting familiarity, signalling the necessity of ongoing feminist interventions in Irish culture.

The positioning of Phillips's body on the blanket and her captivity in the cell tangentially recalled the protest actions of Irish Republican Army (IRA) prisoners held in HM Maze Prison, Belfast and HM Armagh Prison. The term "on the blanket" denoted the refusal of the incarcerated to wear the supplied prison uniforms when their own IRA military dress was taken from them, opting instead to cover their bodies with prison issued bedding. The lack of the identifiable military uniform for IRA prisoners undercut their status as political prisoners, meaning that they were no different than common criminals. In defying authorities and

8. On February 5, 2013 the government released the Report of the Inter-Departmental Committee to establish the facts of State involvement with the Magdalen Laundries. On February 19, 2013 an Taoiseach Enda Kenny issued a full and unreserved apology for the suffering of these women. The means of compensating these women is still unclear.

9. The title of the exhibition referenced the Jesus Jones song by the same name referring to the fall of Eastern European governments in the late 1980s and it contextualized the event as an intervention in Irish history and contemporary issues in Irish society. 
Figure 1 : Áine Phillips, Redress (2010), Performance Still, Photo: (C) Aine Phillips.

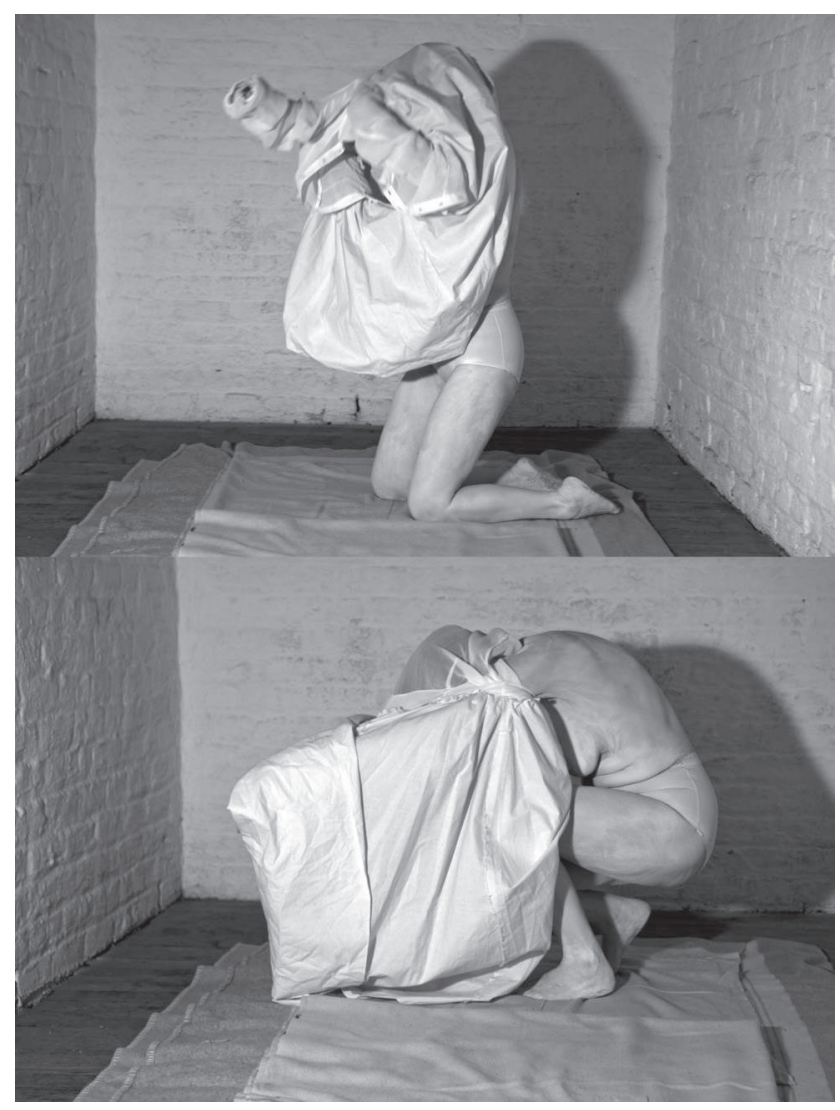

remaining dressed in the blankets, or later entirely naked when denied the blankets, they struggled to maintain bodily autonomy despite their compromised positions. The physicality of Phillips's struggle between her body and the dress established this connection. However, her submissive positions when she knelt down and sprawled out on the blanket lacked the empowerment present in the actions of the Republican prisoners. The repeated physical acts of dressing and undressing also evoked the resulting psychological distress of the abuse against the vulnerable. Her white dress, styled like an old-fashioned nightgown was a stark reminder of the unspeakable transgressions committed against children in residential care. Phillips's earlier works Red Wedding (2005), Red Weight (2006) and Botany of Dresses (2009) used clothing to communicate the weight of the past. The Ryan Report highlighted that the sustained and constant fear experienced by witnesses of various levels of abuse led to psychological damage that "conti- 
nued into adulthood for many witnesses ${ }^{10}$ ". The continuous exposure of the lower half of her body reminded the viewer of the lingering disgrace of abuse, a shame that maintains its power long after the offense is committed. The concealment of Phillips's face by the dress was a suffocating gag; a reminder that the social stigma attached to abuse victims is further compounded by the censoring of those "compensated".

The role of spectatorship and the pleasure of looking, integral to the making of meaning in this performance, can be assessed from a feminist perspective. Phillips remained isolated in the cell throughout the performance while her actions were voyeuristically viewed through the peephole of the closed door (Fig. 2) ${ }^{11}$. This provided an intimate experience of the work as only a singular spectator could observe her. The power implicit in the act of this surveillance was reminiscent of a peep show, in which a display of erotic objects or photographs, or a sex show or pornographic film is accessed through a small round hole, viewing slot or magnifying glass. The circular peephole mimicked an ocular shape stimulating the association between the act of surveillance and the desire to look at Phillips's body. Peep shows employed conventions established in the early mutoscope softcore pornographic films generically titled What the Butler Saw (c. 1895), in which a Butler spies on his mistress in various states of undress through the keyhole of her door ${ }^{12}$. As the shape of the peephole embedded in the cell door essentially narrowed the field of vision, Phillips's body was not always visible in its entirety, at times mimicking hardcore pornographic conventions that represent visually dismembered body parts. However, instead of presenting the viewer with the implied class structure of the servant spying upon the employer, Redress rendered visible the hierarchal structure of the gaze upon the female body, as originally theorised in John Berger's feminist inflected text Ways of Seeing (1971) when he asserted: "Men act, women appear ${ }^{13}$." The one-way mechanism of the peephole, literally a magnifying lens, ensured that viewers could peer into the cell observing her body at their leisure. On the other side of the door Phillips spent four hours uncertain as to if or when her body went unobserved, maintaining the illusion of the woman as constantly surveyed. This functioned in the same way as the panopticon, a prison surveillance mechanism discussed in Michel Foucault's Discipline and Punishment (1979). The design of the

10. The Ryan Report (2009) Volume IV, Section 6.41, [http://www.childabusecommission.com/rpt/04-06.php], accessed June 27, 2012.

11. This also references Cross's Caught in a State (1991) installation of a stillborn foetal pig and a calendar tacked to the wall with images of a sow viewed through the peephole.

12. The mutoscope designed by William Kennedy-Laurie Dickinson was a cheaper version of Thomas Edison's motion picture kinetoscope that functioned like a flip-book. See Katherine Mullin, James Joyce, Sexuality and Social Purity, Cambridge, Cambridge University Press, 2003, p. 145 and Sheila McClear, Last of the Live Nude Girls: A Memoir, Berkeley, Soft Skull Press, 2011, p. 230.

13. John Berger, Ways of Seeing, London, British Broadcasting Corporation and Penguin Group, 1972, p. 45-46. 
panopticon ensured that the presumed presence of the authoritative, controlling gaze acted as a constant regulator over the incarcerated. In this performance this implicit power was coupled with the voyeuristic gaze upon the female body, assuring that the power and pleasure experienced by the viewer provoked awareness of Irish society's complicity in the isolation of victims.

Figure 2 : Aine Phillips, Redress (2010), Performance Still, Photo: (C) Aine Phillips.

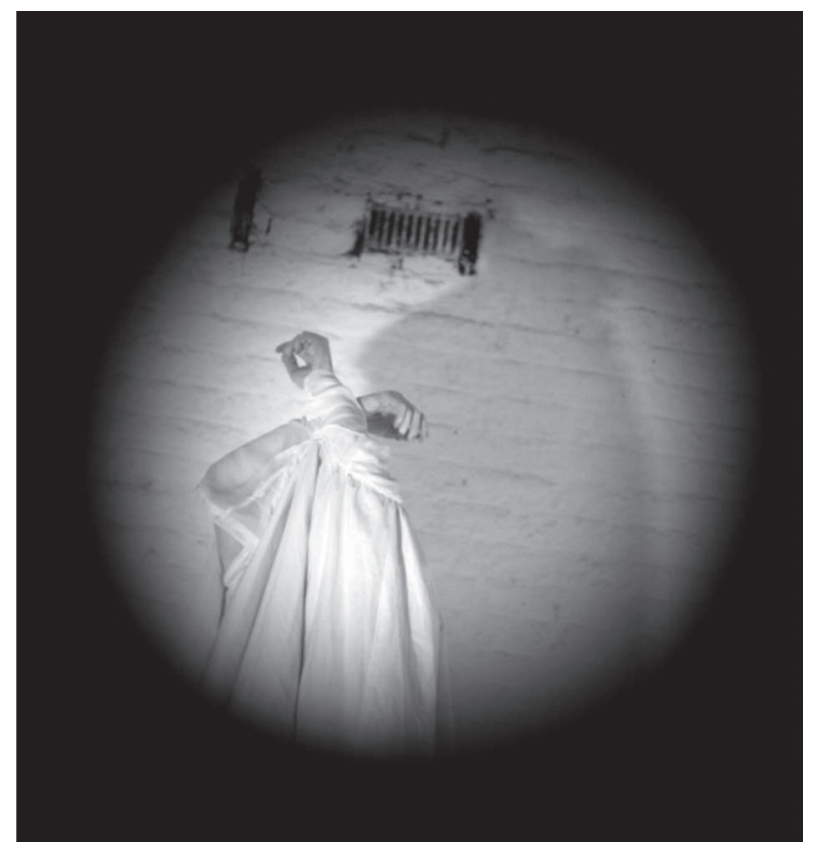

Redress (2010) is indebted to Eadweard Muybridge's (1830-1904) Miscellaneous phases of the toilet (Woman Dressing) (1887, Plate 494). In a series of photographic studies entitled Animal Locomotion: an electro-photographic investigation of consecutive phases of Animal movements (1872-1885) Muybridge detailed the movements of humans and animals through freeze-frame photography underpinned by a sense of detached observation. The correlation to Woman Dressing was evident in the repeated dressing and undressing actions mirroring the thirty-frame composition of Muybridge's photographic plate. In the intimatelysized video work Redress (2010, 5 minutes looped) Phillips's actions were recorded against a grid backdrop recalling the scientific screen that served to capture the exact movements of Muybridge's subjects (Fig. 3) ${ }^{14}$. The cage-like arrangement

14. It was filmed in collaboration with Irish filmmaker Vivienne Dick (b. 1950) and exhibited at Live@8 (Occupy Space, Limerick, 2011). 
of the grid lines acted as an enclosure containing and restricting Phillips's movements. Juxtaposing Woman Dressing and Redress, essentially a freezing and unfreezing of time, reveals the power of an image to construct and unravel an idea. If Muybridge's images splice through time and space to freeze a moment, then performance art unfixes that moment, splaying it open through its reliance on temporality ${ }^{15}$. The fleeting moments of Redress, with its transient visibility and the awareness it affords, communicated the power of performance to activate marginalised memories. The projection of the video through a muslin cloth, softening the focus of the camera's lens, diffused the image of Phillips's body with a distinct bleeding or seeping effect, indicating that the legacy of abuse in twentieth-century Ireland cannot be quietly sequestered.

Figure 3 : Aine Phillips, Redress (2010), Video installation, Photo: Declan Sheridan, (C) Aine Phillips.

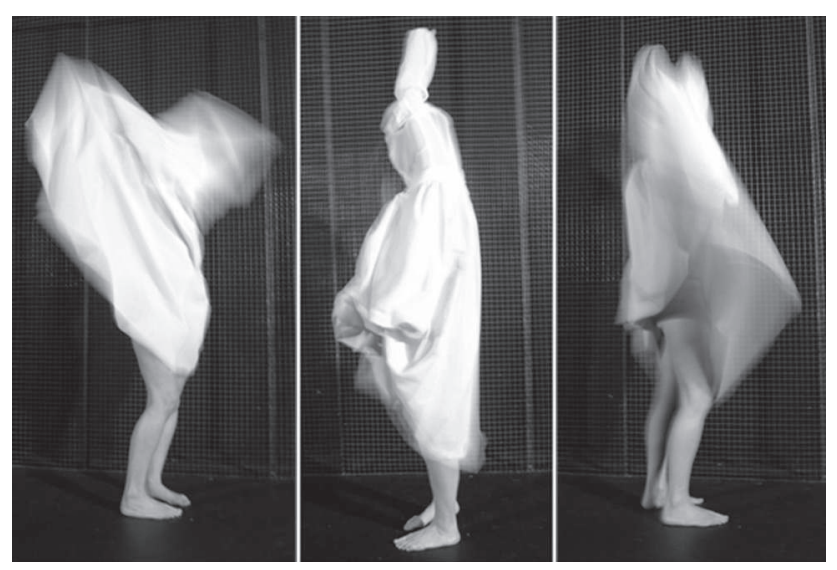

Redress: Emotional Labour (2012) (Fig. 4) is an eight-hour durational performance compellingly framed by ideas of visibility and embodiment in relation to the legacies of abuse. It was performed on three separate occasions as part of Labour, a live exhibition of concurrent durational performances by eleven Irish women artists ${ }^{16}$. Extending the concerns of the first two performances, Redress: Emotional Labour responded to the incarceration of women in the Magdalene Laundries. Its development coincided with the United Nations Committee

15. Joanna Lowry, "Performing vision in the theatre of the gaze: the work of Douglas Gordon", Performing the Body, Performing the Text, eds. Amelia Jones and Andrew Stephenson, London, Routledge, 1999, p. 259.

16. The exhibition was curated by Chrissie Cadman, Amanda Coogan and Helena Walsh. It was held in Performance Space (London), The Void (Derry) and The Lab (Dublin). Several of the participating artists including Michelle Brown (The Grace of God), Chrissie Cadman (Finding a Balance), Áine O'Dwyer (The Cradle Rocks the Land) and Helena Walsh (Untitled) focused explicitly on gender, sexuality and religion in contemporary Irish society. 
Against Torture (UNCAT) recommendation (May 2011) that the Irish government investigate the abuse and inhumane treatment of women incarcerated in the Magdalene Laundry Institutions from 1922 to 1996 in line with UN Convention Number Fourteen. It was divided into three main actions described as "staining (what is hidden is seeping out), crawling (to transform supplication into intimacy) and netting (entanglement and escape) ${ }^{17}$ ". The performance aped the opening and closing times of the gallery meaning that Phillips actions appeared endless.

Figure 4 : Áine Phillips, Redress: Emotional Labour (2012), Performance Still, Photo: Sally Anne Kelly, (C) Áine Phillips.

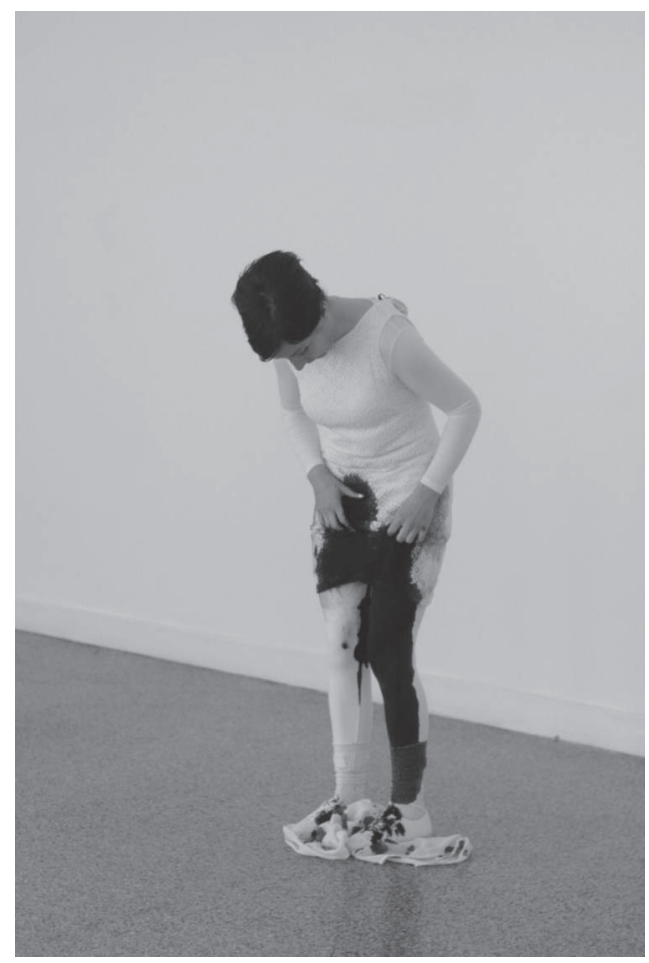

It was developed in collaboration with artist Evelyn Glynn, who recently completed Breaking the Rule of Silence (2011) on the Good Sheppard Magdalene Laundry (1850-1993), Limerick. Glynn's work was a series of drawings, sound and video installations, archival materials and photographs and oral testimonies of those incarcerated at the laundry as well as relatives and patrons who experienced

17. Áine Phillips, "Áine Phillips", Labour: A Live Exhibition, exhibition guide, eds. Sheena Barrett and Amanda Coogan, Dublin, Dublin City Arts Office/the Lab, 2012, unpaginated. 
the facility that demonstrated the chillingly deliberate forgetting and silencing of the traumatic histories of the Magdalene inmates ${ }^{18}$. Named for Mary Magdalene, a companion of Jesus traditionally labeled as a reformed prostitute, the Magdalene Asylums or Magdalene Laundries as they were more commonly known were residential institutions where originally women such as prostitutes and unmarried mothers were sent. In the twentieth century, ten institutions throughout Ireland continued to house these women, while also taking in those who suffered mental disabilities, those referred by their families and women previously cared for in industrial schools. They were expected to repent for their alleged sins by maintaining silence throughout the day, engaging in frequent prayer and working without pay in the laundries. Barred windows and doors prevented these women from leaving the premises. If they did manage to escape, Gardaí returned them to the institutions where many spent the remainder of their lives ${ }^{19}$. Many who died in the confines of the Good Sheppard Laundry were buried in unmarked mass graves at the Mount St. Laurence Cemetery, Limerick ${ }^{20}$. Glynn became painfully aware of the lack of recognition by the college that occupied Laundry's former premises and attempted to counter the suppression of this dark past. Motivated by her own interest in the historically subordinate position of women in Irish society, Phillips collaborated with Glynn to record nine stories from the oral testimonies for the performance Redress: Emotional Labour that were played continuously during the first two actions over a period of six hours.

In the first action, Phillips wore a white lace shift dress that referenced the Limerick Lace produced by women at the Good Sheppard Laundry, a long sleeve shirt, leggings and shoes. Taking small steps, she moved slowly and silently around the space. As she haltingly and repeatedly rubbed her hands against her dress, a viscous black liquid seeped out from her sides. The fresh stains on her hands suggested the unexplained Catholic occurrence of stigmata, a bodily manifestation of suffering that mimics the five wounds inflicted upon Christ during the crucifixion. A large number of reported stigmatics are women and the Dominican Order, in particular, viewed the spiritual gift of stigmata, in addition to other forms of penitence like self-flagellation and bodily prayer poses, as a preparation for "the greater gifts of glory" associated with the resurrection ${ }^{21}$. Yet the black substance in this performance functioned not as a holy mark of Christ, but

18. Fintan O'Toole, "We should be recovering our Magdalen history, not burying it", Irish Times, October 29, 2011.

19. "Justice for Magdalenes helps organise survivor meeting with Senator McAleese", Press Release, Justice for Magdalenes, June 6, 2012, [http://www.magdalenelaundries.com/press]JFM\%20PR\%2007-06-12.pdf], Accessed June 7, 2012.

20. The Magdalene Name Project (2004) named the women buried there, [http://www.magdalenelaundries.com/ name.htm], Accessed June 7, 2012.

21. Maiju Lehmijoki-Gardner, Dominican Penitent Women, Mahwah, New Jersey, Paulist Press, 2005, p. 17. 
rather a mark of disgrace ${ }^{22}$. Next she held her offending hands in front of her, deliberately chaffing them together trying to remove the offending fluid. Used for drawing or writing, the purpose of ink is to inscribe, document or record. The use of the ink refers to the absence of official recognition of the women who toiled in the Magdalene laundries. The shame associated with these women meant that they were not even afforded the dignity of having their full names recorded in the official Irish census. Often buried in unmarked graves, their existence was not only unacknowledged but deliberately erased. The grimy, messy nature of the ink on Phillips's body imbues the performance with an embodied aspect beyond what can be conveyed linguistically. The artist's inability to remove these permeating stains emphasised the impossibility of cleansing Irish history from these offenses.

The corporeal association of the black ink smeared on the body as Phillips continued to wipe her hands on her white dress highlighted the assumed impurity of the women of the Magdalene Laundries. This dark staining can be understood as a marker of the social and moral stigma that promiscuity or sexual relations outside of marriage brought to those women who were deemed as transgressive in their sexual behavior. The location of the seeping, staining fluid around the artist's hips and thighs alluded to menstruation and post-partum vaginal bleeding known as lochia. The abject nature of these visceral bodily secretions, literally crossing over the corporeal boundaries of the body, rendered visible the association of these women who violated conservative societal norms. The oral testimonies, sewn discretely into the dress, meant that Phillips literally embedded the memories of the Other onto her body. In order to clearly hear the testimonies it was necessary for the viewer to stand in close proximity to Phillips establishing an uneasy intimacy between the bodies of the viewer and the artist. Intimacy in performance art can be difficult to negotiate depending on the nature of the actions performed as it may leave one vulnerable. Although it was desirable to stand close to the artist to hear to the testimonies, approaching her while she rubbed her hands in the trance-like state was akin to a violation of her personal space. This reflected the realities of life for the incarcerated women, as neither possessions nor space belonged to them; the assault on their autonomy was constant. The juxtaposed intimacy and invasion of this bodily relationship between artist and spectator presented one with a palpable sense of injustice.

Phillips crawled painstakingly through gallery space wearing black shoes embedded with shards of glass; the constant pressure of her knees against the hard ground appeared to bear the burden of remembering [Fig. 5]. Her exertions became mentally and physically taxing, indicative of the suffering body. The ink smeared traces on the ground served as blemished marks of her existence provi-

22. The word stigmata is also the plural for stigma, indicating a mark of disgrace or disease. 
ding visual evidence of the space that her body once occupied. Hope occasionally surfaced when Phillips initiated bodily contact with a few spectators. As she reached out with one hand to lightly touch the foot of a seated viewer, she momentarily connected artist and viewer through a humbling somatic gesture. Bodily connections in performance encompass transformative potential, according to Rebecca Sachs Norris: "The body [...] recognizes and receives communication directly from other bodies, allowing posture, gesture, and imagery to develop as alternative means of transmitting knowledge and feeling of various states of being 23 ." In this moment, the softly spoken testimonies took on a powerful quality; the words of those who suffered enabled a bodily transference from victim to spectator that essentially functioned as a type of bodily witnessing. Tim Etchells argues "to witness an event is to be present at it in some fundamental way, to feel the weight of things and one's own place in them, even if that place is simply, for the moment, as an onlooker ${ }^{24 "}$. The entreaties of Phillips's actions, likened to supplications, humble prayers or petitions that reference the legacy of Catholicism, begged the audience for acknowledgement and mercy. Transferred onto the body of the viewer or witness via the somatic gesture, the supplication was transformed into a plea for forgiveness. The glass shards on the soles of her feet, though suggestive of enforced penance or atonement, glittered like brittle crystallised tears in an outward manifestation of shared sorrow. The shifting possibility of a physical bodily hierarchy, dependant on the position of the viewer's body, either standing over Phillips or seated on the ground signified the potential complicity of the audience in the act of silencing. As these interactions continued throughout the performance, the balance of power continually fluctuated between witness and unwilling participant, an indication that the quest acknowledgement and empowerment is not straightforward.

For the last two hours of the performance, Phillips, dressed in black, struggled to free herself from a large black net while gripping a ball of black string (Fig. 6). Like the earlier Redress performance her movements were conveyed with a palpable urgency. Rolling on the floor, she appeared ensnared in the legacy of sexual repression and oppression in Irish culture. The darkened string was another reference to Limerick Lace, a luxury item first produced as a result of poverty, dating back to the time of the Great Famine (c.1850). The women in the Good Sheppard Laundry created these delicate, intricate patterns by darning on netting or mesh before tiny stitches were applied to embroider a design ${ }^{25}$. Although Phillips actions did not express the delicacy of the lace making, her body inserted into the

23. Rebecca Sachs Norris, "Embodiment and Community”, Western Folklore 60, 2\&3, 2001, p. 117.

24. Tim Etchells, Certain Fragments: Contemporary Performance and Forced Entertainment, London, Routledge, 1999 , p. 17.

25. Marian Powys, Lace and Lacemaking, Mineola, Courier Dover Publications, 2002, p. 35. 
middle of the snarling mess embodied the intricacies of the craft, suggesting the complex nature of these silenced histories.

\section{Figure 5 : Áine Phillips, Redress: Emotional Labour (2012), Performance Still,} Photo: Sally Anne Kelly, (C) Aine Phillips.

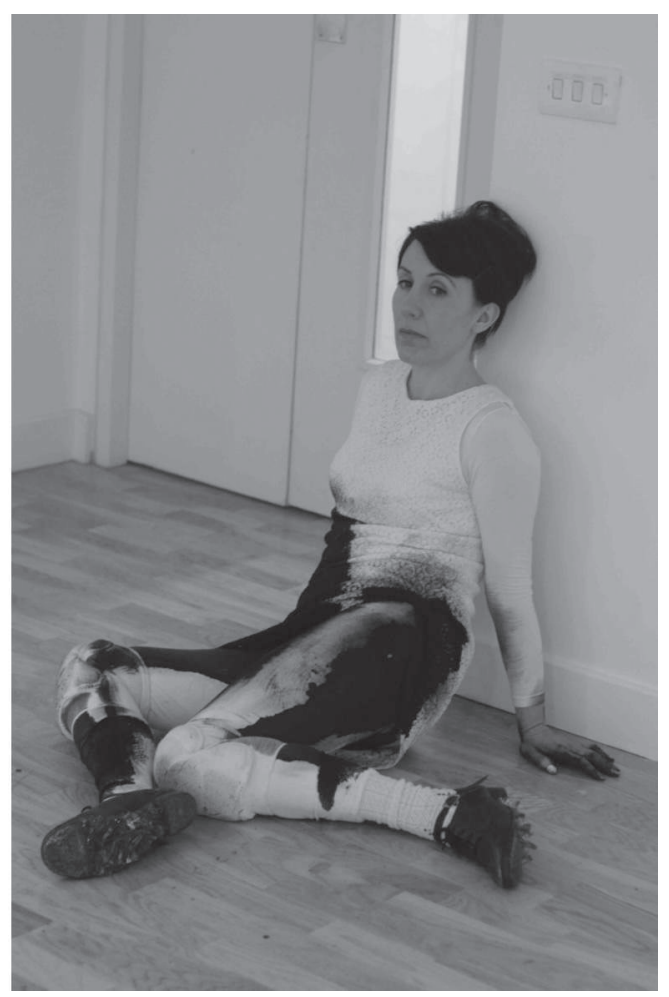

It is necessary to unpack the potential feminist ethical concerns posed by the Redress performances particularly around abuse survivors, their right to speak and the sensitive nature of the subject. Expressing outrage on the silencing of survivors, Phillips remarked: "It is extraordinary that our society doesn't speak out against this ${ }^{26 "}$. Following standard ethical protocols Evelyn Glynn gave interviewees participating in Breaking the Rule of Silence the option of anonymity while consenting that any audio, video recordings and photographs made during the project could be used by researchers, future students, and the public for educational purposes including publications, exhibitions, World Wide Web and presentations. This means that informed consent was not required for usage in Phillips's

26. Live Art Symposium, Áine Phillips and Evelyn Glynn, March 9, 2012. [http://vimeo.com/38499317], accessed May 28, 2012. 
Figure 6 : Áine Phillips, Redress: Emotional Labour (2012), Performance Still, Photo: Jordan Hutchings, (c) Áine Phillips.

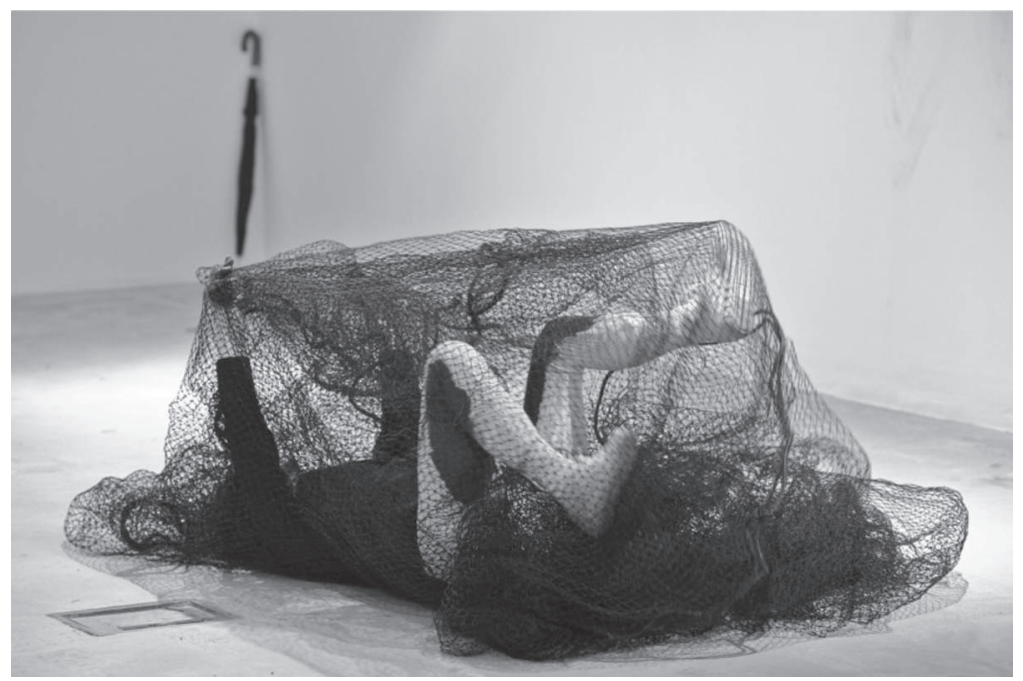

performance. However, an ethical dilemma arises from the artist recording the direct words of an interviewee for use in a live art event. Phillips writes: "It was important for me to use their words because their words are the truth - not a received knowledge or understanding, but their own expressions of authentic lived experience ${ }^{27}$." Other feminist performances have addressed these issues like Karen Finlay's We Keep Our Victims Ready (1990), a stream of consciousness performance that schizophrenically detailed her personal experience of abuse. Yet Phillips's testimonies differ from the provocative vocalizations of Finlay. In rerecording testimonies instead of using the actual interview recordings, Phillips speaks for those who cannot. This may rest uneasily with some observers and raises questions as to the ethical obligations of a feminist performance practice in light of anthropologist Victor Turner's assertions of "performance as making not faking 28 ". The purpose of the performance was not to empower abuse survivors; therefore the inclusion of spoken testimonies was not to claim authenticity. Instead, their incorporation acted as a lens through which Phillips negotiated and exposed the complex issues of shame and stigmatisation that arise from abuse. According to Vikki Bell, "Feminist politics responds to the sufferings of women, and seeks to remedy those sufferings by rooting out injustices on every level ${ }^{29}$ ".

27. Email to the author, January 29, 2013.

28. Victor Turner quoted in Dwight Conquergood, "Of Caravans and Carnivals: Performance Studies in Motion", $T D R, 39,4$ (Autumn, 1995), p. 138.

29. Vikki Bell, Culture and Performance: The Challenge of Ethics, Politics and Feminist Theory, Oxford, Berg, 2007, p. 50. 
Phillips sought to address the disempowerment experienced by abuse survivors by projecting the experiences of complicity and shame onto the audience. It was impossible to remain impassive observers for the silence maintained by artist and audience demanded an awareness that one was actively listening for the gaps and the silences in the broken narratives.

The visible embodiment of shame communicated in both performances denotes the potential for bodily witnessing in the Redress series. In Redress (2010), bodily witnessing occurs in the artist's tiring struggle with her garment. In Redress: Emotional Labour the embedding of oral testimonies directly onto the body of the performer and the process of their translation from survivor to written documentation to Phillips's re-recordings transform into a visual witnessing activated by the shame communicated through her actions. The role of the spectator is also critical for understanding how performance can subvert mechanisms of unacknowledged power through witnessing. The gaze rendered visible these power structures by making the viewer aware of the transgression of looking in Redress (2010) evident through the observation of Phillips imprisoned in her cell in Kilmainhaim Gaol. In Redress: Emotional Labour, hierarchal power structures were revealed through the spectator's experience of their own bodily relationship to the artist, indicated by the desire to transgress the boundaries of personal space to hear the testimonies and through the position of dominance occupied in contrast to Phillips's submissive body. Critically Redress (2010) reinforced the viewer's role as a helpless observer while Redress: Emotional Labour collapsed the distance between performance and viewer.

The collective title of this series, Redress, functions on several different levels. It indicates the attempts to make financial restitution to survivors while also signaling the importance of attempting to address these on-going issues in Irish society. In the context of the embodied performances the title refers to the repeating or duplication of actions. In both performances discussed, Phillips utilised simple bodily repetitions; continually dressing and undressing, ceaselessly rubbing her hands together, crawling on the ground and struggling to free herself from the net. Repetition in live performance, particularly in durational performances, signals a slowing of time, a hindering of "progress" by constantly returning to the scene of some previous experience. In Redress (2010), the repetition of dressing and undressing evoked frustration in the spectator who desired a resolution to her struggle with the garment. The repetitive movement of the artist's hands in Redress: Emotional Labour (2012) conveyed the endless shame and humiliation. The unceasing bodily motions in both performances revealed the permeating nature of abuse and how its legacy and memory continues to violate. Most importantly, the reiterations of specific actions throughout the performances were a reminder that these transgressions against the most vulnerable in Irish society were numerous and widespread. 
Importantly, Redress engenders awareness that the past is not stagnant but continues to haunt the present. Phillips's body acts as a conduit for marginalised memories by simultaneously channelling discourses of feminism, spectatorship and embodiment. Performance art is reliant upon a reciprocal subject-object relationship, meaning that the work is dependent upon specific interactions with viewers in time and space. In performance, the key aspect of time, as a measurement of fixed duration and a notion of temporality, serves to temporarily render visible processes of remembering and forgetting in the construction of cultural narratives. The emphasis placed on process, as something that encourages the viewer to intuitively grasp the embodiment of an idea, rather than to passively view a resulting material object, suggests that feminist performances like Redress hold enormous potential to engage with the gaps and silences of cultural narratives. In particular, the possibility of performance to act as a visual form of witnessing by drawing attention to the potent affects of individual and collective traumas may begin to alleviate the burden of secrecy, isolation and shame that characterises experiences of abuse. Redress urgently calls for recognition of how the forced silencing of survivors contributes to a lingering cultural stigma. These performances demand that respect and dignity are restored to the disempowered within Irish society. 